\title{
STUDI ANALISIS KEMAMPUAN MENGENAL HURUF HIJAIYAH PADA ANAK USIA DINI MELALUI BERMAIN PUZZLE DI KELOMPOK B TK AL-KHAIRAAT KABONENA KOTA PALU
}

\author{
Nurhidayah ${ }^{1)}$ Muh.Jabir ${ }^{2)}$ Rus'an ${ }^{3)}$ \\ ${ }^{1}$ Mahasiswa Program Studi PIAUD FTIK Institut Agama Islam Negeri Palu \\ ${ }^{2}$ Dosen Fakultas Tarbiyah dan Ilmu Keguruan Institut Agama Islam Negeri Palu \\ ${ }^{3}$ Dosen Fakultas Tarbiyah dan Ilmu Keguruan Institut Agama Islam Negeri Palu
}

\begin{abstract}
ABSTRAK
Penelitian ini membahas tentang studi analisis kemampuan mengenal huruf hijaiyah pada anak usia dini melalui bermain puzzle di kelompok B TK Al-khairaat Kabonena Kota Palu. Penelitian ini menggunakan pendekatan kualitatif. Teknik pengumpulan data melalui observasi, wawancara dan dokumentasi. Teknik analisis data yang digunakan adalah reduksi data, penyajian data dan verifikasi data. Hasil penelitian ini menunjukan bahwa peran guru dalam mengenalkan huruf hijaiyah melalui bermain puzzle yaitu Mereka tidak hanya, menyediakan fasilitas ataupun media belajar saja, tetapi juga harus membimbing peserta didiknya yang masih berusia dini dengan mengajarkan pelafalan huruf hijaiyah dengan benar, agar mereka dapat mengenal huruf hijaiyah, serta guru juga harus membiasakan anak untuk mandiri, disiplin, hidup bersih, bertanggung jawab. Guru juga menggunakan beberapa metode pembelajaran yaitu dengan metode bernyanyi dan metode bermain dengan menggunakan media puzzle agar para peserta didik tidak bosan. Guru mengenalkan huruf hijaiyah pada peserta didik sesuai dengan perkembangan anak dan melakukan kegiatan pembelajaran melalui bermain. Penerapan bermain puzzle dalam meningkatkan kemampuan mengenal huruf hijaiyah pada Anak Usia Dini di TK Al-Khairaat Kabonena Kota Palu, dilaksanakan pada hari jum'at, cara memainkanya dengan membongkar, menyusun serta mencocokan kembali puzzle sesuai dengan bentuk dan susunan urutannya.
\end{abstract}

Kata Kunci : Huruf Hijaiyah, Anak Usia Dini, Bermain Puzzle.

\section{PENDAHULUAN}

Pendidikan merupakan kebutuhan mutlak bagi kehidupan manusia yang harus dipenuhi. Pemenuhan kebutuhan pendidikan merupakan tanggung jawab bersama antara lingkungan keluarga (orang tua), lingkungan masyarakat dan lingkungan sekolah (lembaga pendidikan). Pendidikan adalah usaha sadar dan sistematis untuk mewujudkan suasana belajar dan proses pembelajaran sedemikian rupa agar peseta didik dapat mengembangkan potensi dirinya secara aktif agar memiliki pengendalian diri, kecerdasan, keterampilan dalam bermasyarakat, kekuatan spiritual keagamaan, kepribadian serta akhlak mulia yang dimulai sejak Pendidikan Anak Usia Dini 
(PAUD), Sekolah Dasar (SD), Sekolah Menengah Pertama (SMP), Sekolah Menengah Atas (SMA).

Pendidikan Anak Usia Dini (PAUD) adalah suatu upaya pembinaan yang ditujukan kepada anak sejak lahir sampai dengan usia enam tahun yang dilakukan melalui pemberian rangsangan pendidikan untuk membantu pertumbuhan dan perkembangan jasmani dan rohani agar anak memiliki kesiapan dalam memasuki pendidikan lebih lanjut. ${ }^{1}$ Pendidikan Anak Usia Dini (PAUD) merupakan salah satu tahapan pendidikan yang dapat menentukan pertumbuhan dan perkembangan anak dimasa depannya. ${ }^{2}$ Seiring berkembangnya pemikiran tersebut, tuntutan dan kebutuhan layanan Pendidikan Anak Usia dini cenderung semakin meningkat. Pendidikan Anak Usia Dini diselenggarakan pada jalur formal, non formal dan informal. Jalur formal pendidikan Anak Usia dini berbentuk Taman Kanak-kanak (TK) dan Raudhatul Athfal (RA) sedangkan jalur non formal berbentuk Kelompok Bermain (KB) dan Tempat Penitipan Anak (TPA). Sementara pendidikan informal berbentuk pendidikan keluarga atau pendidikan yang dilaksanakan oleh lingkungan.

Anak pada usia Taman Kanak (TK) merupakan masa yang sangat penting dalam mengenalkan konsep seperti konsep bilangan dan huruf. Karena hal tersebut huruf hijaiyah juga hendaknya diajarkan pada Anak Usia Dini khususnya anak yang ada di usia Taman Kanak-kanak (TK), karena Huruf hijaiyah merupakan bahasa Al-Qur'an dan Al-Qur'an merupakan salah satu pedoman bagi setiap orang muslim.

Huruf Hijaiyah merupakan Alfabeta Arab yang disebut dengan huruf al hija (iyah) dan huruf al tahajj artinya ejaan. Huruf al 'Arabiyah itu terdiri dari huruf yang bertanda baca atau bertitik ( $h u r u f$ al- mu'jam), baik dalam bentuk terpisah-pisah yang belum dipahami kecuali menjadi sebuah rangkaian kata ataupun sebagian atu seluruhnya telah ditandai dengan tanda baca. ${ }^{3}$ Huruf hijaiyah berjumlah 29 huruf. Huruf Hijaiah adalah Ejaan Bahasa Arab yang merupakan bahasa asli dalam AlQur'an. Pengenalan Huruf hijaiyah merupakan kunci dasar untuk mampu membaca Al-Qur'an dan hadis, dan bagi setiap muslim hal tersebut sudah menjadi pedoman pokok kehidupan untuk memahaminya. Pengenalan huruf hijaiyah pada Anak Usia Dini tidaklah sama dengan mengajar huruf hijaiyyah pada orang dewasa. Pengenalan huruf hijaiyah pada Anak usia Dini dapat dilakukan dengan berbagai cara salah satunya bermain sambil belajar, hal ini dilakukan bertujuan untuk menarik perhatian anak.

Dalam proses bermain sambil belajar tersebut akan semakin lebih mudah mendapat pengalaman dan pengetahuan apabila menggunakan media yang bermanfaat dan mengandung unsur edukatif. Salah satu media untuk bermain tersebut adalah 2015), 45

${ }^{1}$ Helmawati, Mengenal Dan Memahami PAUD, (Bandung: PT. Remaja Rosdakarya,

${ }^{2}$ Suyadi, Maulidya Ulfah, Konsep Dasar PAUD, (Bandung: PT. Remaja Rosdakarya, 2015), 2.

${ }^{3}$ Sigit Purnama, Pembelajaran Al-Qur'an untuk Anak usia Dini, (Yogyakarta: State Islamic University Sunan Kalijaga, 2017), 98. 
puzzle huruf hijjaiyah. Puzzle merupakan salah satu Alat Permainan Edukatif (APE) yang berupa kepingan tipis terdiri dari 2-3 bahkan 4-6 potongan terbuat dari kayu, karton, busa, karet, tripleks dan steroform. Alat permainan edukatif merupakan alat permainan yang dirancang secara khusus untuk kepentingan pendidikan yang bertujuan untuk meningkatkan aspek-aspek perkembangan anak.

Sekolah Taman Kanak-kanak Al-Khairaat Kabonena adalah salah satu sekolah Taman Kanak-kanak yang ada di Kecamatan Ullujadi dan satu-satunya yang ada di kelurahan Kabonena dan ikut andil dalam melaksanakan pendidikan untuk mempersiapkan generasi yang berkualitas. Sekolah ini menggunakan model pembelajaran Area. Model Pembelajaran Area adalah model yang lebih memberikan kesempatan kepada anak didik untuk memilih atau melakukan kegiatan sendiri sesuai dengan minatnya. Dan masing-masing area banyak memiliki alat permainan edukatif salah satunya puzzle huruf hijaiyah. Berdasarkan berbagai alasan yang sudah diuraikan itulah mendorong peneliti untuk melakukan penelitian dengan judul "Studi Analisis Kemampuan Mengenal Huruf Hijaiyah Pada Anak Melalui Bermain Puzzle di kelompok B TK Al-Khairaat Kabonena Kota Palu".

\section{METODE PENELITIAN}

Jenis penelitian yang digunakan dalam penelitian ini adalah penelitian kualitatif. Lokasi penelitian yakni di TK Al-Khairaat Kabonena Kota Palu. Sumber data primer diperoleh melalui wawancara kepada Kepala Sekolah TK Al-Khairaat, serta beberapa orang guru di TK Al-Khairaat kabonena. Sedangkan, data sekunder diperoleh melalui dokumentasi, dan catatan yang berkaitan dengan objek penelitian, disamping itu yang menjadi pelengkap dan lainnya yang menunjuk kondisi sekolah TK Al-Khairaat Kabonena seperti sarana dan prasarana sekolah, keadaan sekolah, keadaan guru serta keadaan siswa dan data lainnya yang berhubungan terhadap objek penelitian.

Teknik pengumpulan data yang digunakan adalah teknik observasi, dokumentasi dan wawancara. Adapun teknik analisis data yang dilakukan meliputi reduksi data, penyajian data dan verifikasi data. Data-data yang telah didapatkan dari lokasi penelitian sangat penting untuk dicek kembali, agar benar-benar memperoleh data yang akurat sesuai harapan. Penelitian kualitatif dinyatakan absah apabila memiliki derajat kepercayaan (credibility), keteralihan (transferability), kebergantungan (Dependability), dan kepastian (confirmability). ${ }^{4}$

Pengecekan keabsahan data dilakukan dengan tujuan untuk memperoleh data yang akurat, pengecekan keabsahan data dilakukan dengan cara mengoreksi data satu persatu agar dapat diketahui kesalahan-kesalahan yang ada, kemudian akan disempurnakan lebih lanjut.

${ }^{4}$ Djam'an Satori, Aan Komariah, Metodologi Penelitian Kualitatif, (Bandung: Alfabeta, 2012), 164 
Dalam pengecekan keabsahan data ini penulis menggunakan pengecekan melalui diskusi dengan berbagai kalangan yang memahami masalah penelitian ini yaitu dengan teman-teman yang sudah memahami dan berpengalaman mengenai analisis kemampuan mengenal huruf hijaiyah pada anak melalui bermain puzzle.

\section{HASIL DAN PEMBAHASAN}

\section{Pengenalan Huruf Hijaiyah Pada Anak Usia Dini Melalui Bermain Puzzle Di kelompok B TK Al-Khairaat Kabonena}

\section{Peran Guru dalam Mengenalkan Huruf Hijaiyah melalui Bermain Puzzle}

Peran guru di TK Al-Khairaat Kabonena pada kegiatan pembelajaran khususnya pembelajaran pengenalan huruf hijaiyah melalui bermain puzzle, guru tidak hanya menyediakan alat bermain berupa puzzlenya saja tetapi guru juga harus mengajarkan anak bagaimana cara memainkannya seperti cara membongkar dan menyusun kembali mainan puzzlenya agar tersusun sesuai dengan susunan yang benar. Terkadang guru juga harus berperan layaknya seorang ibu karena harus pintar membujuk anak yang tidak mau bermain dengan teman-teman yang lain karena biasanya malu sebab belum mengetahui cara memainkan puzzle ataupun anak yang tidak mau berbagi mainan puzzle dengan yang lain. Dalam kegiatan pengenalan huruf hijaiyah pada Anak Usia Dini melalui bermain puzzle di TK Al-Khairaat Kabonena khususnya di kelompok B, pelaksanaan kegiatan belajarnya sesuai dengan Rencana Program Pembelajaran Harian (RPPH) yang dibuat oleh guru agar tujuan pembelajaran dapat tercapai. Sebagaimana yang diungkapkan oleh wali kelas B2 sebagai berikut:

Semua kegiatan belajar mengajar yang dilakukan dalam satu hari dilaksanakan sesuai dengan Rencana Program Pembelajaran Harian (RPPH) yang dibuat oleh guru-guru agar semua kegiatan program semester dapat terlaksana dan dapat mencapai tujuan pembelajaran. ${ }^{5}$

Metode yang biasa digunakan oleh guru dalam kegiatan belajar mengajar khususnya pengenalan huruf hijaiyyah pada Anak Usia Dini di sekolah TK Al-khairaat Kabonena, selain menggunakan metode Tanya jawab guru juga menggunakan beberapa metode lain seperti metode bernyanyi dan metode bermain. Pengenalan huruf hijjaiyah pada Anak Usia Dini di sekolah TK Al-Khairaat sering dilaksanakan pada hari Jum'at, hal ini sesuai dengan hasil wawancara peneliti dengan salah satu guru di TK Al-Khairaat Kabonena.

${ }^{5}$ Reni, Wali Kelas B2, “Wawancara” di ruang kelas B2 TK Al-Khairaat Kabonena, tanggal 12 januari 2018. 
Pengenalan huruf hijaiyah disekolah TK ini, sering dilakukan pada hari jum'at, setelah anak melakukan beberapa kegiatan belajar lainnya, seperti praktek sholat berjamaah, mewarnai, menyambung huruf dan lain-lain. ${ }^{6}$

Dari pemaparan hasil wawancara tersebut, peneliti berasumsi bahwa tidak hanya pengenalan huruf hijaiyyah saja yang diprioritaskan oleh guru tetapi mereka juga tentang pelaksanaan praktek sholat berjamaah dan kegiatan-kegiatan yang dapat merangsang perkembangan kognitif dan lain sebagainya.

\section{Penerapan Bermain Puzzle Dalam Meningkatkan Kemampuan Mengenal Huruf Hijaiyah Pada Anak Usia Dini Di TK Al-Khairaat Kabonena}

Seperti yang sudah dijelaskan pada pemaparan hasil wawancara diatas, bahwa pengenalan huruf hijaiyah melalui bermain puzzle dilaksanakan sesuai Rencana Program Pembelajaran Harian (RPPH) dan biasanya dilakukan pada hari Jum'at setelah melakukan kegiatan pembelajaran yang lain. Menurut pengamatan peneliti, dalam pengenalan huruf hijaiyah melalui bermain puzzle di sekolah TK Alkhairaat Kabonena, memiliki urutan kegiatan yaitu sebagai berikut:

a. Kegiatan awal

Pada kegiatan awal ini berlangsung sekitar \pm 30 menit. kegiatan yang dilakukan oleh peserta didik yaitu berbaris didepan kelas, dan guru membimbing salah seorang peserta didik untuk memimpin barisan. Selanjutnya guru mengajak anak bernyanyi sambil melakukan gerakan tubuh yang sesuai dengan lagu yang dinyanyikan, adapun lagu yang sering dinyanyikan dalam kegiatan berbaris yaitu Lonceng Berbunyi, Matahari Bersinar Terang Dan Bom-Bom Mari Berbaris. Contoh lagu "lonceng berbunyi" yang dinyanyikan yaitu:

Lonceng berbunyi

Baris di halaman

Bersiap kaki rapat

Pegang pundak teman

Tangan ke atas, lalu di rentang

Sekarang ke bahu, ke muka, di pinggang,

Loncat yang tinggi 1,2,3,

Mari meniru burung terbang di udara.

Adapun tujuan dari kegiatan ini yaitu agar anak dapat merasa senang sebelum masuk kedalam kelas, selain itu juga agar dapat melatih motorik kasar pada anak karena ada gerakan pada anggota tubuh, sebagaimana pemaparan salah seorang guru kelas B2 TK Al-Khairaat Kabonena.

${ }^{6}$ Reni, Wali Kelas B2, “Wawancara” di ruang kelas B2 TK Al-Khairaat Kabonena, tanggal 12 januari 2018. 
Tujuan dari kegiatan bernyanyi sambil menggerakan anggota tubuh ini yaitu agar anak-anak merasa senang, mungkin sebelum berangkat sekolah mereka ada yang merasa sedih dengan hal-hal tertentu. Bukan hanya itu saja tetapi juga dapat melatih motorik kasar pada anak karena didalam kegiatan bernyanyi tadi ada juga gerakan anggota tubuh. ${ }^{7}$

Selanjutnya setelah kegiatan baris-berbaris, guru mengarahkan peserta didik untuk masuk kedalam kelas masing-masing, namun sebelumnya guru memberikan nasehat-nasehat seperti melepas sepatu sebelum masuk kedalam kelas, tidak berebutan masuk kedalam kelas, dan sebelum masuk kedalam kelas harus memberi salam serta mencium tangan ibu guru (salim). Setelah peserta didik sudah masuk didalam kelas, guru kembali mengarahkan peserta didik untuk duduk di atas karpet dengan sopan dan tertib. Dari pengamatan peneliti, di kegiatan ini guru dan peserta didik melakukan doa bersama. Adapun bacaan doa yang sering dibaca yaitu, doa sebelum masuk ke dalam kelas, dua kalimat syahadat, bacaan surah-surah pendek seperti: Al-Fatiha, An-Naas dan Al-Falaq. Kemudian bacaan doa sebelum belajar, doa untuk kedua orang tua dan doa kebaikan dunia dan akhirat. Setelah kegiatan berdoa bersama selesai, guru mengajak anak kembali bernyanyi dengan beberapa lagu seperti: "selamat pagi dan nama-nama hari". Setelah bernyanyi, guru melakukan Tanya jawab kepada peserta didik. Guru bertanya tentang nama hari, tanggal, bulan dan tahun. Kemudian guru bercakap-cakap tentang tema dihari itu, guru bertanya kepada anak tentang kegiatan pembelajaran yang sudah dilakukan kemarin dan guru juga menjelaskan tentang kegiatan yang akan dilakukan di hari itu, yaitu seperti tentang kegiatan praktek sholat dan pengenalan huruf hijaiyah.

\section{b. Kegiatan Inti}

Menurut pengamatan peneliti, pada kegiatan inti berlangsung sekitar \pm 60 menit. Pada kegiatan inti ini dilakukan kegiatan praktek sholat dan pengenalan huruf hijjaiyyah. Sebelum melakukan kegiatan pengenalan huruf hijaiyyah terlebih dahulu peserta didik melakukan kegiatan praktek sholat berjamaah melalui arahan dan bimbingan guru. selanjutnya setelah melakukan praktek sholat berjamaah, guru langsung melakukan kegiatan pembelajaran pengenalan huruf hijaiyyah. adapun pengenalan huruf hijaiyah disini, guru menggunakan beberapa media yaitu media gambar berupa poster dan media Alat Permainan Edukatif (APE) berupa Puzzle huruf hijaiyah. adapun langkah awal yang dilakukan guru dalam pengenalan huruf hijaiyah disini,terlebih dahulu guru mengajak anak duduk diatas karpet yang berhadapan langsung dengan gambar poster huruf hijaiyah, pada kegiatan ini guru menggunakan

${ }^{7}$ Reni, Wali Kelas B2, "Wawancara” di ruang kelas B2 TK Al-Khairaat Kabonena, tanggal 19 januari 2018. 
metode Tanya jawab terhadap peserta didik, dengan guru terlebih dahulu menjelaskan nama-nama huruf hijaiyah yang ada di gambar poster tersebut. Bukan hanya dengan metode Tanya jawab saja, guru juga menggunakan metode bernyanyi pada saat mengenalkan huruf hijaiyah dengan menggunakan media gambar poster. Dan selanjutnya guru memanggil satu persatu peserta didik untuk maju kedepan untuk menyanyikan lagu huruf hijaiyah sambil menunjukan huruf-huruf hijaiyah yang ada di poster, seperti yang sudah dicontohkan guru. namun, dari pengamatan peneliti hanya ada beberapa orang anak saja yang mampu menyebutkan serta menujuk huruf yang benar dan yang sesuai dengan lagu tentang huruf yang dinyanyikan, dan sebagian besar peserta didik hanya menghafal lagu huruf hijaiyah saja akan tetapi tidak begitu mengenal bentuk-bentuk huruf hijaiyah. jadi pada saat menunjuk gambar poster huruf hijaiyah dengan nyanyian, banyak peserta didik yang belum begitu mengenal huruf hijaiyah, dengan kata lain, huruf yang ditunjuk tidak sesuai dengan huruf yang diucapkan. Selanjutnya guru mengenalkan huruf hijaiyah dengan media puzzle. Disini guru menunjukan dan menjelaskan tentang cara menggunakan atau cara memainkan media puzzle huruf hijaiyah kepada peserta didik. Dari pengamatan peneliti, adapun cara memainkan media puzzle yang dijelaskan oleh guru kepada peserta didik yaitu membongkar, kemudian menyusun dan mencocokan kembali sesuai dengan urutan huruf yang benar. Para peserta didik terlihat senang dan penasaran dengan alat permainan tersebut. Kemudian guru mengarahkan anak untuk duduk di kursi, dan kemudian guru membagi para peserta didik menjadi beberapa kelompok. Hal ini bertujuan untuk mengajarkan peserta didik bekerja sama dengan teman kelompoknya dan mengembangkan aspek sosial emosional peserta didik, hal ini sesuai dengan ungkapan guru kelas B2.

Pembagian kelompok ini dilakukan dengan tujuan agar anak mulai belajar bekerja sama dengan teman kelompoknya dan hal ini juga dapat mengembangkan sosial emosional peserta didik. ${ }^{8}$

Kemudian guru langsung membagikan alat permainan puzzle huruf hijaiyah kepada masing-masing kelompok. Dan setelah itu guru menjelaskan bagaimana cara menyusun kepingan puzzle huruf hijaiyyah. Disini guru tidak hanya menjelaskan saja, tetapi guru juga menemani serta membimbing peserta didik dalam menyusun puzzle huruf hijaiyah. guru juga mengenalkan huruf hijaiyah pada peserta didik dimulai dari huruf yang paling mudah diucapkan. selanjutnya masing-masing kelompok mulai bekerja sama dalam membongkar, menyusun, serta mencocokan kembali kepingan puzzle huruf hijaiyah, disini peneliti mengamati bahwa peserta didik mulai memunculkan kemampuan mereka dalam mengenal huruf hijaiyah, karena pada saat

${ }^{8}$ Reni, Wali Kelas B2, “Wawancara” di ruang kelas B2 TK Al-Khairaat Kabonena, tanggal 19 januari 2018. 
menyusun kepingan puzzle, mereka tidak hanya pandai dalam meyesuaikan bentuk pasangannya saja tetapi mereka juga mampu menyebutkan nama huruf hijaiyah apabila ditanya oleh guru. walaupun masih ada beberapa orang anak yang masih belum mengenal semua nama huruf hijaiyah, guru dikelas ini selalu berusaha mengenalkan huruf hijaiyah yang belum diketahui peserta didik tersebut, menggunakan berbagai metode dengan media yang ada yaitu media puzzle. Dari pengamatan peneliti, salah satu cara guru dalam mengenalkan huruf hijaiyah melalui media puzzle kepada peserta didik yang belum mengetahuinya yaitu:

"Anak-anak, huruf yang bentuknya seperti perahu dan di atasnya ada tiga titik itu namanya huruf, tsa $(\dot{)})$ dan huruf yang perutnya gendut ada titik satu di atasnya itu namanya huruf, kho $(\dot{\bar{c}})$ ". 9

Pada saat menjelaskan dengan cara tersebut, guru mengajak peserta didik untuk mengambil salah satu kepingan puzzle yang dimaksud dan menunjukannya sambil menyuruh menyebutkan nama hurufnya. Bukan hanya itu saja, guru juga mengajarkan peserta didik, untuk belajar menyusun kepingan puzzle secara berurutan sesuai dengan susunan hurufnya. Meskipun demikian guru tidak memaksakan peserta didik yang belum begitu paham, agar harus cepat paham seperti teman-teman lain yang sudah paham.

Pada kegiatan pembelajaran tentang pengenalan huruf hijaiyyah pada Anak Usia Dini melalui bermain puzzle ini, menurut pengamatan peneliti bahwa para peserta didik merasa senang dengan permainan puzzle huruf hijaiyah tersebut, disebabkan karena puzzle yang dimainkan memiliki warna bermacam-macam yang dapat menarik perhatian peserta didik. Bukan hanya itu saja guru juga menggunakan metode yang asyik dan dapat menarik perhatian peserta didik, hal ini dapat dilihat peneliti karena para peserta didik sangat antusias dalam memainkan puzzle, karena rasa senang inilah yang membuat para peserta didik bisa lebih memahami dan mengenal huruf hijaiyah. Selanjutnya, setelah para peserta didik di masing-masing kelompok telah menyusun kepingan puzzle secara berkelompok, guru mengarahkan lagi kepada peserta didik untuk menyusun kepingan puzzle secara perorangan atau perindividu sesuai jumlah puzzle yang ada. Karena jumlah puzzle huruf hijaiyah di kelas B2 sebanyak lima buah maka para peserta didik yang lain harus menunggu giliran berikutnya. Di kegiatan ini guru juga mengadakan tanya jawab kepada masing-masing peserta didik yang sedang menyusun kepingan puzzle tentang nama huruf hijaiyyah yang disusun. Disini guru dapat mengetahui lebih detail tentang kemampuan peserta didik dalam mengenal huruf hijaiyyah. Selanjutnya apabila peserta didik telah selesai menyusun kepingan puzzle huruf hijaiyah, guru langsung memberikan atau mengumumkan nilai kepada peserta didik tersebut. Dari pengamatan peneliti, adapun cara pemberian nilai kepada peserta

${ }^{9}$ Hasil observasi, di ruang kelas B2 TK Al-Khairaat Kabonena, tanggal 19 januari 20018 
didik disini tidak berupa angka melainkan dengan simbol bintang (*). Nilai tertinggi adalah peserta didik yang mendapat empat bintang (****) dan nilai terendah adalah peserta didik yang mendapat satu bintang (*).

c. Kegiatan Akhir

Kegiatan akhir ini berlangsung sekitar \pm 30 menit. Setelah peserta didik selesai istirahat, mereka memasuki kelas dan duduk diatas karpet. Disini peneliti mengamati, guru menenangkan suasana kelas yang ribut dengan mengajak anak bernyanyi bersama. Kemudian guru mengajak anak bercakapap-cakap dengan mengulas kembali tentang kegiatan yang telah dilakukan dari awal hingga akhir. Dan selanjutnya peserta didik berdoa bersama sebelum pulang.

Berdasarkan pengamatan peneliti lakukan, pengenalan huruf hijaiyah di TK AlKhairaat Kabonena, tidak hanya menggunakan media Puzzle saja tetapi juga menggunakan beberapa media lain seperti gambar dan kartu huruf hijaiyah.

\section{KESIMPULAN}

Berdasarkan uraian yang telah dikemukakan pada pembahasan-pembahasan pada bab sebelumnya, maka peneliti dapat mengemukakan beberapa kesimpulan antara lain sebagai berikut:

1. Peran guru dalam mengenalkan huruf hijaiyah melalui bermain puzzle yaitu guru tidak hanya menyediakan fasilitas ataupun media belajar saja, adapun peran guru yaitu:

a. Guru harus mengajar sekaligus membimbing peserta didik, agar mereka dapat mengetahui dan mengenal huruf-huruf hijaiyah, serta mereka juga dapat mengetahui cara memainkan permainan puzzle huruf hijaiyah. Pada kegiatan pembelajaran pengenalan huruf hijaiyah melalui bermain puzzle.

b. Guru mengenalkan huruf hijaiyah pada peserta didik dimulai dari huruf yang paling mudah diucapkan.

c. Guru juga harus berperan seperti layaknya seorang ibu karena harus pintar membujuk peserta didik yang tidak mau berbagi mainan dengan temannya.

2. Penerapan bermain puzzle dalam meningkatkan kemampuan mengenal huruf hijaiyah pada Anak Usia Dini di kelompok B TK Al-Khairaat kabonena dilakukan secara berkelompok dan secara individu. Adapun cara bermain puzzle huruf hijaiyyah yaitu dengan cara membongkar kemudian menyusun dan mencocokan kembali susunan hurufnya dengan benar sesuai dengan urutannya.

\section{IMPLIKASI PENELITIAN}

Berdasarkan hasil penelitian yang dilakukan tentang Kemampuan Mengenal Huruf Hijaiyah Pada Anak Usia Dini Melalui Bermain Puzzle, maka peneliti mengemukakan beberapa saran yaitu: 
1. Bagi pembaca diharapkan dapat menambah wawasan dan ilmu tentang kemampuan mengenal huruf hijaiyah pada Anak Usia Dini melalui bermain Puzzle.

2. Bagi kepala sekolah diharapkan lebih memperhatikan sarana dan prasarana sekolah baik media maupun alat permainan edukatif yang ada di kelas, khususnya tentang pengenalan huruf hijaiyah, agar guru tidak menemukan kesulitan selama kegiatan pembelajaran dan para pesrta didik semakin bersemangat dalam mengikuti kegiatan pembelajaran.

3. Bagi guru, perlu kiranya guru lebih bervariatif dalam memberikan kegiatan pembelajaran khususnya dalam pengenalan huruf hijaiyyah melalui bermain puzzle, sehingga anak dapat lebih antusias dan lebih tertarik dalam mengikuti kegiatan pembelajaran. Motivasi dan bimbingan perlu lebih ditingkatkan oleh guru agar dapat memacu semangat belajar anak.

\section{DAFTAR PUSTAKA}

Helmawati, Mengenal Dan Memahami PAUD, Bandung: PT. Remaja Rosdakarya, 2015.

Purnama, Sigit. Pembelajaran Al-Qur'an untuk Anak usia Dini, Yogyakarta: State Islamic University Sunan Kalijaga, 2017.

Reni, Wali Kelas B2, "Wawancara” di ruang kelas B2 TK Al-Khairaat Kabonena, tanggal 12 januari 2018.

Satori, Djam'an. Komariah, Aan. Metodologi Penelitian Kualitatif, Bandung: Alfabeta, 2012.

Suyadi, Maulidya Ulfah, Konsep Dasar PAUD, Bandung: PT. Remaja Rosdakarya, 2015. 